\title{
Pendampingan Komunitas Sekolah Melalui Upaya Pemanfaatan Lahan Tidur sebagai Media dan Sumber Belajar Berbasis Lingkungan
}

\author{
Syaiful Rizal, Sulis Hendrawati, Siti Nur Afifah, Titin Mariatul Qiptiyah \\ Institut Agama Islam (IAI) Al-Qodiri Jember \\ E-mail: syaifulrizal212@gmail.com
}

\section{Article History:}

Received: Feb $13^{\text {th }} 2020$

Revised: July $11^{\text {th }} 2020$

Accepted: Nov 30th 2020

Keywords: school community, idle land use, environmental-based media and learning resources.

\begin{abstract}
Pre-school education (TK) adheres to the principle of "playing while learning or learning while playing". Therefore, the learning activities should be carried out inside and outside the classroom or schoolyard. The use of the schoolyard as idle land plays an important role in the process of teaching and learning activities in early childhood education because it can be used as a target, facility, media, and learning resources which are based on the environment. The focus of this service is the development of community assets of TK Dharma Wanita 02 on the quality aspects of teacher human resources in utilizing the schoolyard as a medium and learning resource during the Covid-19 pandemic. The service method employs the Asset Based Community Development (ABCD) approach. This program results in the use of the school grounds at TK Dharma Wanita 02 as an alternative environmental-based media and learning resource to support learning during the Covid-19 pandemic.
\end{abstract}

\section{Pendahuluan}

Undang-Undang Sistem Pendidikan Nasional (2003) pada pasal 1 ayat (14) menyatakan bahwa pendidikan anak usia dini (PAUD) adalah suatu upaya pembinaan yang ditujukan kepada anak sejak lahir sampai dengan usia enam tahun yang dilakukan melalui pemberian rangsangan pendidikan untuk membantu pertumbuhan dan perkembangan agar anak memasuki pendidikan lebih lanjut. ${ }^{1}$ Pengetahuan serta pembelajaran bagi anak usia dini didapat dari lingkungan mereka, yaitu keluarga, masyarakat dan lembaga pendidikan. PAUD merupakan salah satu bentuk penyelenggaraan pendidikan yang menitikberatkan pada peletakan dasar ke arah pertumbuhan dan perkembangan fisik (koordinasi motorik halus dan kasar), kecerdasan

1 D. A. Walujo and A. Listyowati, Kompendium PAUD. Memahami PAUD Secara Singkat (Depok: Prenadamedia Grup, 2017). 
(daya pikir, daya cipta, kecerdasan emosi, kecerdasan spiritual), sosio emosional (sikap dan perilaku serta agama) bahasa dan komunikasi, sesuai dengan keunikan dan tahaptahap perkembangan yang dilalui oleh anak usia dini. ${ }^{2}$ Menurut Hadawi, esensi dari PAUD adalah pemberian rangsangan atau stimulasi pendidikan yang sesuai dengan tahap tumbuh-kembang anak dan dilaksanakan melalui pendekatan bermain sambil belajar. ${ }^{3}$

Lembaga pendidikan formal yang mendidik anak usia dini dikenal dengan Kelompok Bermain (KB) dan Taman Kanak-kanak (TK). Peraturan Pemerintah Nomor 27 Tahun 1990 menyatakan bahwa TK adalah salah satu bentuk pendidikan prasekolah yang menyediakan program pendidikan dini bagi anak usia empat tahun sampai memasuki pendidikan dasar. Dimana tugas utama TK adalah mempersiapkan anak dengan memperkenalkan berbagai pengetahuan, sikap/perilaku, keterampilan dan intelektual agar dapat melakukan adaptasi dengan kegiatan belajar yang sesungguhnya di Sekolah Dasar (SD). Taman Kanak-Kanak merupakan bentuk pendidikan pra sekolah yang menyediakan program pendidikan dini yang diperlukan oleh siswa dalam menyesuaikan diri dengan lingkungannya dan untuk kehidupan selanjutnya. Solehuddin mengatakan bahwa pendidikan pra sekolah yang diwujudkan sebagai Taman Kanakkanak pada hakekatnya adalah tempat anak bermain sambil belajar atau belajar sambil bermain. Anak-anak TK masuk sekolah sebenarnya adalah untuk bermain dan mengenal lingkungan 4 . Pemerintah Indonesia di bidang pendidikan pra sekolah juga menganut prinsip "bermain sambil belajar atau belajar seraya bermain". Oleh karena itu, kegiatan pembelajaran bagi murid TK semestinya dilakukan di dalam ruang kelas maupun di luar kelas atau halaman (Pekarangan) sekolah. ${ }^{5}$

Pemanfaatan pekarangan sekolah menjadi salah satu sarana yang berperan penting dalam proses kegiatan belajar mengajar di lembaga pendidikan anak usia dini, karena dapat dijadikan sebagai sasaran belajar, sarana belajar, media dan sumber belajar. Selain dekat dengan ruang belajar siswa, Pemanfaatan pekarangan sekolah sebagai media dan sumber belajar sekaligus dapat membantu memperjelas konsep-konsep abstrak (sukar dinalar oleh siswa) menjadi konkrit (lebih mudah difahami) dan menjadikan proses belajar mengajar lebih menyenangkan.

Para guru yang tidak menyadari akan pentingnya pemanfaatan pekarangan sekolah dalam kegiatan belajar mengajar. Dengan adanya pembelajaran yang tidak memanfaatkan ruang kelas ada beberapa manfaat yakni: (1) kegiatan pembelajaran lebih menarik dan tidak membosankan; (2) bahan-bahan yang dipelajari lebih kaya serta lebih faktual sehingga kebenaranya lebih akurat, (3) sumber belajar lebih kaya sebab lingkungan yang dapat dipelajari bisa beraneka ragam; (4) hakikat belajar akan lebih 2018).

2 M. Habibi, Analisis Kebutuhan Anak Usia Dini (Buku Ajar S1 PAUD) (Yogyakarta: Deepublish,

${ }^{3}$ Kartika, "Perlukah Anak Diikutkan PAUD?," Kompas.Com.

${ }^{4}$ Muh Barid Nizarudin Wajdi, "Spiritual Counseling As An Alternative Problem Solving," Educatio : Journal of Education 1, no. 2 (October 30, 2016): 11-28, accessed October 18, 2017, http://ejournal.staimnglawak.ac.id/index.php/educatio/article/view/27.

${ }^{5}$ Solehuddin, Konsep Dasar Pendidikan Prasekolah (Bandung: FIP IKIP Bandung, 1997). 
bermakna sebab siswa dihadapkan dengan situasi dan keadaaan yang sebenarnya atau bersifat alami; dan (5) membuat setiap individu memiliki kesempatan unik untuk mengembangkan kreativitas dan inisiatif personal. Di lembaga TK Dharma Wanita 02 guru dalam proses belajar mengajar kurang memanfaatkan asset yang ada, yakni pekarangan sekolah. Sehingga pembelajaran monoton lebih sering berada di dalam kelas. Pembelajaran siswa AUD yang berorientasi di dalam kelas berdampak pada siswa yang merasa bosan, dan apabila siswa AUD merasa bosan bisa dipastikan perhatian siswa berkurang, mengantuk yang mengakibatkan tujuan belajar tidak tercapai.

Sebagai salah satu bentuk upaya memanfaatkan pekarangan sekolah sebagai media dan sumber belajar, maka peneliti sebagai pelaku pemberdayaan melakukan pendampingan menciptakan sekolah pekarangan di komunitas lembaga TK Dharma Wanita 02 Desa Sukosari Kecamatan Sukowono Kabupaten Jember. Sekolah TK ini memiliki pekarangan sekolah yang luas yang terintegrasi dengan pekarangan Kantor Desa Sukosari Sukowono. Halaman yang luas dan potensial tersebut kurang maksimal dan optimal dimanfaatkan oleh guru dalam kegiatan belajar mengajar. Dengan kenyataan tersebut, maka sekolah pekarangan merupakan salah satu langkah yang solutif untuk mengatasi masalah diatas. Hasil penelitian Titiek dan Rini6 menunjukkan bahwa pemanfaatan Halaman (pekarangan) sekolah di TK Al Ikhlas Lempongsari dan TK Sumberan Telah mampu memberikan dampak dalam proses kegiatan belajar mengajar sebab Siswa merasa senang karena dapat bermain dan belajar lewat lingkungan sekitar sekolah yakni pekarangan sekolah. Maka, pemanfaatan lingkungan sekolah secara maksimal dapat menyelesaikan permasalahan problem kegiatan belajar mengajar yang monotun di komunitas lembaga TK Dharma Wanita 02.

Ada beberapa faktor yang menjadi alasan lain dalam memilih dampingan di komunitas lembaga TK Dharma Wanita 02 Desa Sukosari Kecamatan Sukowono Kabupaten Jember, yaitu sebagai berikut. Pertama, TK Dharma Wanita 02 Desa Sukosari merupakan lembaga yang memiliki problem dalam pengajaran. Problem tersebut adalah pendidik dan tenaga pendidik di lembaga ini tidak sesuai kualifikasi kependidikan, dari 4 pendidik dan tenaga pendidik hanya 1 yang memenuhi kualifikasi kependidikan yang lainnya lulusan SLTA/Sederajat. Kedua, TK Dharma Wanita 02 Desa Sukosari memiliki halaman sekolah yang luas dan terintegrasi dengan halaman kantor Desa Sukosari, sayangnya potensial tersebut kurang maksimal dan optimal dimanfaatkan oleh guru dalam kegiatan belajar mengajar. Problematika tersebut bertambah dengan nuansa sekolah yang minim tanaman sehingga membuat suasana yang seharusnya Nampak indah, bagus dan mendukung pembelajaran tidak ada. Ketiga, TK Dharma Wanita 02 Desa Sukosari mengharapkan bantuan dampingan atau pemberdayaan untuk mengatasi masalah tersebut. Lembaga ini yakin apabila solusi sekolah pekarangan ini diterapkan, maka permasalahan pembelajaran di lembaga ini akan terselesaikan. Keempat, partisipasi masyarakat sekitar sangat bagus untuk mengatasi persoalan ini. Mereka akan

6 Titiek Widyastuti and Rini Juni Astuti, "Penataan Halaman Sekolah Sebagai Ekoedukasi," Berdikari : Jurnal Inovasi dan Penerapan Ipteks 4, no. 1 (2016): 54-62. 
siap membantu pendamping dan tim untuk mewujudkan tujuan tersebut. Kelima, Bapak Kades dan Ibu Kades Sukosari sangat mendukung akan dampingan tersebut mengingat lokasi pekarangan lembaga TK Dharma Wanita 02 Desa Sukosari terintegrasi dengan pekarangan Kantor Desa Sukosari. Terlebih Ibu Kades Sukosari merupakan salah satu tenaga pendidik di TK Dharma Wanita 02.

Kelebihan yang dimiliki TK Dharma Wanita 02 Desa Sukosari yang perlu di akomodir adalah semangat untuk mengembangkan proses kegiatan belajar mengajar yang lebih baik. Semangat guru-guru tersebut menjadi pondasi dan modal utama untuk mengoptimalkan tujuan yang sudah ditetapkan yaitu menciptakan sekolah pekarangan di komunitas lembaga TK Dharma Wanita 02 Desa Sukosari. Upaya mewujudkan tujuan ini selain didukung oleh masyarakat sekitar serta didukung penuh oleh aparatur Desa Sukosari termasuk Kades dan Ibu Kadesnya.

Berdasarkan penjelasan dan realita kondisi dampingan tersebut diatas, menunjukkan bahwa komunitas lembaga TK Dharma Wanita 02 membutuhkan pemberdayaan atau pendampingan untuk mengatasi problematika kegiatan belajar mengajar yang kurang optimal. Cara untuk mengatasi hal tersebut, maka tujuan pemberdayaan yang akan dilakukan adalah pengembangan aset komunitas lembaga TK Dharma Wanita 02 pada aspek kualitas SDM Guru dalam memanfaatkan pekarangan sekolah sebagai media dan sumber belajar di masa pandemi Covid-19. Tujuan ini diharapkan menjadi tujuan dalam memberdayakan lembaga TK Dharma Wanita 02.

\section{Metode}

Program pendampingan di komunitas lembaga TK Dharma Wanita 02 Desa Sukosari Kecamatan Sukowono Kabupaten Jember menggunakan pendekatan Asset Based Community Development (ABCD). ${ }^{7}$ Pendekatan ABCD adalah suatu metode pengabdian yang berupaya untuk mengembangkan Komunitas Berbasis Aset (potensi), Seperti mengembangkan komunitas pendidikan, ekonomi, dan sebagainya. Inti dari pendekatan ABCD adalah upaya untuk memberdayakan dan mengembangkan komunitas sesuai dengan aset yang sudah dimiliki baik asset Individu, Asosiasi, Institusi, Fisik atau Materi, maupun Koneksi atau jaringan komunikasi yang luas. ${ }^{8}$ Adapun asset yang dikembangkan di komunitas lembaga TK Dharma Wanita 02 adalah asset SDM guru dan asset fisik atau materi "pekarangan sekolah".

Pendekatan ABCD mencari cara bagi individu dan seluruh komunitas berkontribusi pada pengembangan mereka sendiri dengan cara: (1) Mengidentifikasi aset-aset yang dimiliki; (2) Meningkatkan kapasitas dan kemampuan dalam mengelola aset; (3) Mendorong untuk melakukan perubahan yang lebih baik; dan (4) Membangun mimpi, memvisualisasikannya dan merumuskan cara bagaimana mewujudkannya.

${ }^{7}$ Nurul Anam, Buku Pedoman Kuliah Kerja Mahasiswa (KKM) Berbasis Asset Based Community Development (ABCD) Tahun Akademik 2019/2020 (Jember: LP3M IAI Al-Qodiri Jember, 2020).

8 Ibid. 
Metode ABCD mempuyai langkah kunci untuk melakukan riset pendampingan, yaitu: Define (Menentukan), Discovery (menemukan), Dream (Impian), Design (merancang), dan Destiny (melakukan). ${ }^{9}$ Adapun langkah-langkah siklus 5-D yang akan diterapkan di komunitas lembaga TK Dharma Wanita 02 Desa Sukosari diilustrasikan pada Gambar 1.

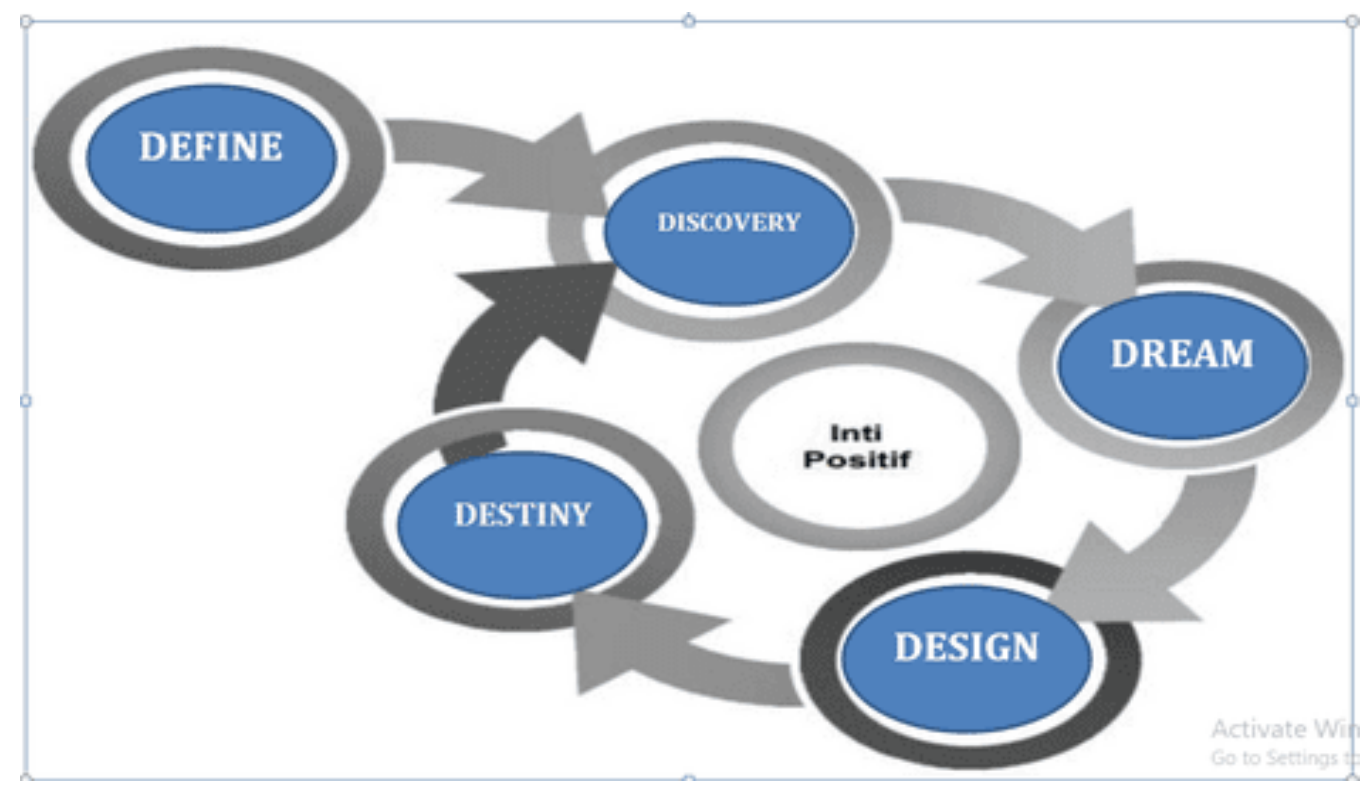

Gambar 1. Langkah-Langkah Siklus 5-D Yang Akan Diterapkan di Komunitas Lembaga TK Dharma Wanita $02^{10}$

Ilustrasi proses langkah-langkah atau tahapan-tahapan siklus 5-D yang digunakan oleh ABCD di atas sebagai berikut: Pertama, Define (Menentukan). Pendamping atau pelaku pemberdayaan menentukan "pilihan topik" dalam melakukan pendampingan di masyarakat. ${ }^{11}$ Topik yang ditentukan di Komunitas Lembaga TK Dharma Wanita 02 adalah Pengembangan Komunitas TK Menuju Lembaga TK yang Unggul dan Tangguh berbasis Pekarangan di Tengah Pandemi Covid-19. Kedua, Discovery (Penemuan Mendalam) terkait tentang mencari dan mengidentifikasi 5 asset yang dimiliki oleh komunitas TK Dharma Wanita 02, masalah yang dihadapi komunitas dan sebagainya. Ketiga, Dream (Impian). Setelah menemukan 5 asset yang dimiliki komunitas TK Dharma Wanita 02 dan fokus asset yang akan dikembangkan, maka langkah selanjutnya adalah merumuskan keinginan atau tujuan untuk mengembangkan asset tersebut yang digagas bersama-sama dengan melibatkan stakeholder. ${ }^{12}$

9 Ahmad Badrut Tamam and Siti Fahimah, "Pengembangan Agrowisata Berbasis Komunitas Melalui Program Edukasi Wisata Dan Entrepreneurship Menuju Kemandirian Ekonomi Masyarakat," Engagement: Jurnal Pengabdian Kepada Masyarakat 4, no. 1 (2020): 100-115.

10 Dirjen Pendis, "Keputusan Direktur Jenderal Pendidikan Islam Nomor 3091 Tahun 2020 Tentang Paradigma Pengabdian Kepada Masyarakat Tahun 2020” (Kementerian Agama, 2020).

11 Ibid.

12 Tim, Panduan KKN ABCD, UIN Sunan Ampel Surabaya: Asset Based Community-Driven Development (ABCD), Pusat Penelitian Dan Pengabdian Pada Masyarakat (Surabaya: SAP 
Keempat, Design (Mendesain atau Merancang). Pada tahap ini, memulai untuk merumuskan strategi, proses dan sistem, membagi peran dan tanggung jawab, membuat keputusan dan mengembangkan kolaborasi yang mendukung terwujudnya penyelesaian masalah di komunitas TK Dharma Wanita 02 dan perubahan yang diharapkan dari komunitas. Kelima, Deliver atau Destiny (Melaksanakan dan Mengontrol atau Mengevaluasi). Pada tahap ini dimana setiap orang dalam organisasi mengimplementasikan berbagai hal termasuk pelaksanaan dan pengontrolan atau pengevaluasian program dampingan terhadap komunitas Lembaga TK Dharma Wanita 02 yang sudah dirumuskan pada tahap define, discovery, dream dan design.

Berdasarkan analisis di atas subjek pemberdayaan di komunitas lembaga TK Dharma Wanita 02 Desa Sukosari yang didasarkan pada kebutuhan dan yang diharapkan oleh komunitas tersebut. Maka subjek dampingan yang akan didampingi dan dikembangkan kualitasnya adalah guru-guru TK Dharma Wanita 02. Jumlah gurunya adalah 4 perempuan yaitu Ibu Siti Fatimah, S.Pd (sekaligus sebagai Kepala Sekolah), Ibu Hawati, Ibu Yuliana, dan Ibu Fasihah.

\section{Hasil}

\section{Tahap Define}

Tahap ini Pendamping atau pelaku pemberdayaan menentukan "pilihan topik" dalam melakukan pendampingan di masyarakat. Di dalam tahapan ini terdapat beberapa langkah yang dilakukan yaitu: a) menentukan topik. Topik ini ditentukan pada tanggal 28 Agustus 2020 oleh Kelompok 12 dan DPL. Topik yang ditentukan yaitu: Pengembangan Komunitas TK Menuju Lembaga TK yang Unggul dan Tangguh berbasis Pekarangan di Tengah Pandemi Covid-19; b) menentukan komunitas dampingan. Setelah melalui rapat dan koordinasi antara kelompok 12 dan DPL maka komunitas yang akan dikembangkan asetnya adalah komunitas lembaga TK Dharma Wanita 02 Desa Sukosari, Sukowono Jember; c) melakukan kesepakatan bekerjasama dengan mitra (komunitas dampingan). Surat kerjasama ini disepakati dan ditanda tangani pada tanggal 08 September 2020 di Komunitas Lembaga TK Dharma Wanita 02 Desa Sukosari, Sukowono Jember. Penentuan topik dan komunitas tersebut berdasarkan hasil survey atau data awal di Komunitas Lembaga TK Dharma Wanita 02 Desa Sukosari, Sukowono Jember yang menunjukkan bahwa komunitas tersebut layak untuk diberdayakan. 


\section{Tahap Discovery}

Pada tahapan ini, pendamping atau pelaku pemberdayaan melakukan proses pencarian yang mendalam, seperti mencari dan mengidentifikasi 5 aset yang dimiliki komunitas, masalah yang dihadapi komunitas dan sebagainya. Untuk melaksanakan dan mengoptimalkan proses discovery, maka harus digunakan berbagai metode atau alat instrumen. Adapun metode atau alat instrumen discovery yang digunakan di Komunitas Lembaga TK Dharma Wanita 02 adalah ada enam alat instrumen Discovery yaitu Inquiry Based Silaturrahim, Community Mapping, Pemetaan Asosiasi dan Institusi, Individual Inventory Skill, Aktifitas komunitas, dan Penentuan program bisa menggunakan skala prioritas. Tahap transek atau penelusuran wilayah tidak digunakan dalam pemberdayaan ini karena tahap ini tidak terlalu mempunyai pengaruh terhadap keberhasilan pemberdayaan ini.

Adapun penjelasan hasil dari enam alat instrumen Discovery tersebut yaitu sebagai berikut: Pertama, Inquiry Based-Silaturrahim. Setelah menentukan topik dan komunitas yang akan diberdayakan, maka langkah selanjutnya melakukan silaturrahim ke lembaga komunitas tersebut yakni dengan Kepala Sekolah TK Dharma Wanita 02 Ibu Siti Fatimah. Hasil silaturahmi "wawancara dan observasi" dilapangan didapati bahwa guru-guru kurang memanfaatkan dan mengoptimalkan pekarangan Sekolah dalam kegiatan belajar mengajar sebagai media dan sumber belajar siswa. Pembelajaran yang dilakukan oleh guru berorientasi atau sering berada di dalam kelas, padahal pekarangan sekolah luas dan terintegrasi dengan pekarangan Kantor Desa Sukosari kurang lebih lahan yang tidak terpakai sekitar $750 \mathrm{M}^{2}$. Nuansa sekolahnya masih minim tanaman yang akan membuat suasana nampak lebih indah, bagus dan mendukung proses pembelajaran. Background 3 guru TK masih keluaran SLTA/Sederajat. Selain itu, kompetisi antara lembaga PAUD dan sekitar cukup ketat, karena di sekitar lingkungan komunitas tersebut masih ada lembaga komunitas PAUD yang lain. Ditambah lagi, guru-guru TK Dharma Wanita 02 jarang mengikuti Pelatihan, Seminar atau Workshop. Serta tidak ada upaya komunitas untuk mengembangkan lembaga ini dalam memanfaatakan dan mengembangkan pekarangan sekolah sebagai media dan sumber belajar siswa.

Kedua, Community Mapping. Langkah ini merupakan upaya untuk melakukan pemetaan asset yang dimiliki oleh Komunitas Lembaga TK Dharma Wanita 02 Desa Sukosari Kecamatan Sukowono Kabupaten Jember. Adapun hasilnya dapat dilihat pada Gambar 2.

Ketiga, Pemetaan Asosiasi dan Institusi. Adapun hasil pemetaan asosiaasi dan institusi di komunitas TK Dharma Wanita 02 adalah sebagai berikut: a) Asosiasi Guru TK Kecamatan Sukosari Jember memiliki peran cukup dominan terhadap pengembangan komunitas TK Dharma Wanita 02. b) Asosiasi IDI Cabang Jember memiliki peran kurang dominan terhadap pengembangan komunitas TK Dharma Wanita 02. c) Institusi Prodi PIAUD IAI Al-Qodiri Jember memiliki peran kurang dominan terhadap pengembangan komunitas TK Dharma Wanita 02, dan d) Institusi desa Sukosari memiliki peran cukup dominan terhadap pengembangan komunitas TK Dharma Wanita 02. 


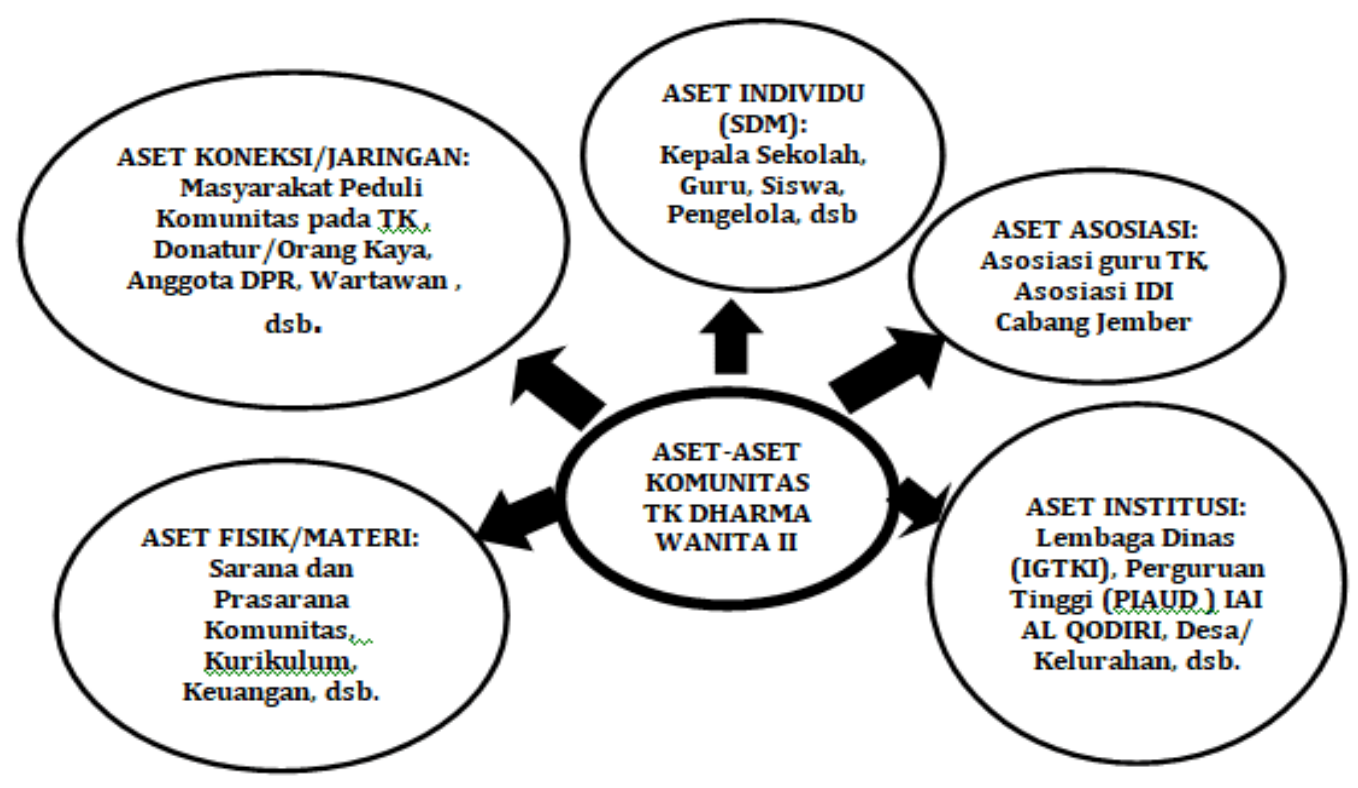

Gambar 2. Hasil Pemetaan Asset Komunitas Lembaga TK Dharma Wanita 02 Desa Sukosari

Keempat, Individual Inventory Skill. Adapun hasil pemetaan kemampuan yang dimiliki asset individu SDM guru di Komunitas Lembaga TK Dharma Wanita 02 adalah: (1) Kepala Sekolah dan guru TK Dharma Wanita 02 mengajarnya cukup bagus, menguasi pengetahuan sangat bagus tetapi, kurang menguasai pemanfaatan pekarangan sebagai media dan sumber belajar yang efektif; (2) Kepala Sekolah dan guru TK Dharma Wanita 02 memiliki kemampuan sosial cukup bagus, dan kemampuan kepribadian bagus; dan (3) Kepala Sekolah dan guru TK Dharma Wanita 02 cukup kreatif.

Kelima, Aktifitas Komunitas. Berbagai aktifitas yang mendukung terhadap keberadaan dan pengembangan komunitas lembaga TK Dharma Wanita 02 yaitu: (1) mendapat bantuan dari pemerintah (BOP); (2) mendapatkan iuran SPP dan iuran pendaftaran; (3) guru pernah mengikuti kegiatan pelatihan; (4) Lembaga Berbeda naungan (Kementrian) tetapi masih Asset Desa; (5) adanya dukungan ADD Desa; dan (6) guru mendapat insentif dari Desa.

Keenam, Penentuan program bisa menggunakan skala prioritas. Hasil penentuan program dengan skala prioritas di Komunitas Lembaga TK Dharma Wanita 02 adalah : a) Asset Individu SDM yang kurang menguasai pemanfaatan pekarangan sebagai Media dan Sumber Belajar dalam pembelajaran yang efektif ternyata cukup berpengaruh terhadap kualitas pembelajaran new normal, hasil belajar dan motivasi belajar siswa. b) Peran Asset Asosiasi yang kurang dominan ternyata kurang berpengaruh terhadap kualitas pembelajaran new normal, hasil belajar dan motivasi belajar siswa, dan c) Peran Asset Instintusi yang kurang dominan ternyata kurang berpengaruh terhadap kualitas pembelajaran new normal, hasil belajar dan motivasi belajar siswa. 


\section{Tahap Dream}

Pada pendampingan ini, merupakan mimpi atau keinginan atau tujuan yang diharapkan komunitas dampingan dalam mengembangkan asset (potensi) komunitas. Hasil rumusan tujuan atau impian yang diinginkan adalah mengembangkan kualitas SDM Guru pada aspek memanfaatkan pekarangan sekolah sebagai media dan sumber belajar di masa pandemi Covid-19 dan mengembangkan kualitas Guru TK dalam menciptakan dan menerapkan lembaga pendidikan TK berbasis Pekarangan Sekolah.

\section{Tahap Design}

Proses ini memulai untuk merumuskan strategi, proses dan sistem, membagi peran dan tanggung jawab, membuat keputusan dan mengembangkan kolaborasi yang mendukung terwujudnya penyelesaian masalah komunitas dampingan dan perubahan yang diharapkan dari komunitas dampingan. Hasil desain program yang akan dilakukan untuk mewujudkan keinginan, impian atau tujuan yang telah ditetapkan tersebut yaitu: a) Merumuskan strategi program dampingan. Strategi program dampingan berbentuk Pelatihan dan Pendampingan. Bentuk-bentuk program yang akan dilakukan yaitu: (1) Pelatihan dan Pendampingan Pengembangan Kualitas Guru TK dalam Menciptakan dan Menerapkan Lembaga TK yang Unggul dan Tangguh berbasis Pekarangan di Tengah Pandemi Covid-19; dan (2) Launching Lembaga TK yang Unggul dan Tangguh berbasis Pekarangan di Tengah Pandemi Covid-19.

Menyusun proses program dampingan. Proses penyusunan proses program dampingan berkaitan dengan beberapa hal sebagai berikut: (1) waktu pelaksanaanya. Pelaksanaan program tersebut dilaksanakan pada Hari Rabu Tanggal 16 September 2020, Program yang akan dilakukan adalah Pelatihan dan Pendampingan Pengembangan Kualitas Guru PAUD dalam Menciptakan Lembaga TK yang Unggul dan Tangguh berbasis Pekarangan di Tengah Pandemi Covid-19. Pelaksanaan program dampingan penciptaan sekolah pekarangan. Sedangkan Program Launching Lembaga TK yang Unggul dan Tangguh berbasis Pekarangan di Tengah Pandemi Covid-19 dilaksanakan pada Hari Rabu Tanggal 14 Oktober 2020; (2) pelaksanaan pelatihan dan dampingan tersebut akan dilakukan di Komunitas Lembaga TK Dharma Wanita 02 Desa Sukosari; (3) pematerinya yang melakukan pendampingan adalah Tim Pemberdayaan IAI Al-Qodiri Jember yang dipimpin oleh Syaiful Rizal, S.Pd.I., M.Pd; dan (4) SDM yang terlibat dalam acara tersebut adalah Guru TK Dharma Wanita 02 Desa Sukosari. Membuat keputusan dan mengembangkan kolaborasi dengan berbagai Asosiasi, Institusi dan Konesi. Untuk mensukseskan acara ini maka Tim Pemberdayaan IAI Al-Qodiri Jember yang dipimpin oleh Syaiful Rizal, S.Pd.I., M.Pd melakukan kerjasama dengan Asosiasi Guru TK (IGTKI), Institusi PAUD Diknas Jember, Institusi PIAUD IAI Al-Qodiri Jember, Institusi Aparatur Desa, Masyarakat sekitar yang peduli pada Komunitas TK Dharma Wanita 02 Desa Sukosari, para Donatur dan Wartawan. 


\section{Tahap Deliver atau Destiny}

Pada tahap ini dilakukan beberapa kegiatan: (1) Pelatihan dan Pendampingan dengan Tema "Pengembangan Kualitas Guru TK dalam Menciptakan Lembaga TK yang Unggul dan Tangguh berbasis Pekarangan di Tengah Pandemi Covid-19"; (2) Penyusunan proses pendampingan dalam menciptakan sekolah pekarangan yakni mendesain ulang atau redesign taman sekolah dengan peletakan batu alam, paving, pengecatan, dan melukis area pekarangan sekolah. Serta penanaman tanaman hias, sayuran, obat-obatan dan sebagainya ditaman sekolah tersebut; dan (3) Program Launching Lembaga TK yang Unggul dan Tangguh berbasis Pekarangan di Tengah Pandemi Covid-19.

\section{Diskusi}

Ada banyak sekali metode dan cara dalam proses pemberdayaan masyarakat, meskipun banyak ragam pemberdayaan tetapi semua metode itu memiliki beberapa persamaan diantaranya adalah pada tujuan akhirnya. Tujuan akhir dari semua metode adalah adanya "chage" atau perubahan pada masyarakat. Perubahan bisa dilihat dari banyak aspek bisa aspek fisik maupun aspek psikis, seperti perubahan "mindset", perubahan di bidang perekonomian atau kesejahteraan, perubahan dalam partisipasi, perubahan dalam kemandirian dan sebagainya. ${ }^{13}$

Pada pengabdian yang dilakukan oleh fasilitator di TK Dharma Wanita 02 terdapat 5 tahapan inti yakni tahap Define, Discovery, Dream, Design dan Deliver sebab fasilitator mengunakan pendekatan ABCD (Asset Based Community Development). Kelima tahapan tersebut merupakan tahapan penting dalam senario besar proses pendampingan menggunakan pendekatan ABCD. Dengan pendekatan ABCD mendorong masyarakat atau komunitas untuk menginventarisir semua asset yang dimilikinya, baik asset materi maupun asset non materi. Aset- aset tersebut kemudian dijadikan sebagai modal awal untuk mengembangkan masyarakat. Dengan kata lain, strategi pemberdayaan masyarakat yang dilakukan adalah berdasarkan atas pemetaan aset-aset yang dimiliki masyarakat, sehingga diharapkan program-program penelitian \& pengabdian masyarakat yang dikembangkan akan sesuai dan sejalan dengan keadaan, kebutuhan, serta harapan masyarakat. Tujuan utama pendekatan ABCD dalam pendampingan ini adalah menumbuhkan kemandirian masyarakat. ${ }^{14}$

Pelaksanaan pemberdayaan dikomunitas TK Dharma Wanita 02 telah dilaksanakan berbagai tahapan diatas, dimana menghasilkan pengembangan asset kualitas SDM Guru pada aspek memanfaatkan pekarangan sekolah sebagai media dan

13 Amal Taufiq and Habib R., "Revitalisasi Kelompok Wanita Tani (KWT) Melalui Pemanfaatan Pekarangan Rumah Di Desa Metesih Kecamatan Jiwan Kabupaten Madiun," Engagement: Jurnal Pengabdian Kepada Masyarakat 2, no. 2 (2018): 204-220.

14 Tamam and Fahimah, "Pengembangan Agrowisata Berbasis Komunitas Melalui Program Edukasi Wisata Dan Entrepreneurship Menuju Kemandirian Ekonomi Masyarakat.” 
sumber belajar di masa pandemi Covid-19. Hal tersebut sesuai dengan Muhammad Efen ii $^{15}$ yang mengatakan bahwa semua lingkungan yang ada disekitar kita bisa digunakan sebagai media dan sumber pembelajaran terutama bagi anak usia dini. Lingkungan merupakan media dan sumber belajar yang banyak berpengaruh terhadap proses pembelajaran yang berlangsung. Lingkungan merupakan bagian dari manusia khususnya bagi peserta didik untuk hidup dan berinteraksi dengan sesamanya. Lingkungan sekolah yang ada di sekitar anak-anak merupakan salah satu media dan sumber belajar yang dapat digunakan dalam proses pembelajaran. Dan jika guru mengajar dengan memanfaatkan lingkungan sebagai media dan sumber belajar maka akan lebih bermakna karena siswa dihadapkan pada kenyataan dan peristiwa yang sebenarnya. ${ }^{16}$ Dengan pengembangan asset pekarangan sekolah tersebut maka Komunitas TK Dharma Wanita 02 memiliki banyak alternatif media dan sumber belajar yang lebih bervariatif. Media dan sumber belajar tersebut berasal dari pekarangan sekolah yang dapat dimanfaatkan dan digunakan oleh guru serta siswa di komunitas TK Dharma Wanita 02.

Sebenarnya, inti pemberdayaan di komunitas TK Dharma Wanita 02 merupakan suatu upaya untuk mengatasi masalah yang ada di komunitas tersebut. Sebagaimana penjelasan-penjelasan sebelumnya, permasalahan yang diprioritaskan untuk diselesaikan adalah SDM guru TK Dharma Wanita 02 yang kurang menguasai pengetahuan tentang pemanfaatan pekarangan sekolah sebagai media dan sumber belajar yang sangat efektif dan efesien. ${ }^{17}$ Untuk mengatasi masalah tersebut, Maka pendamping atau pelaku pemberdayaan akan membantu komunitas TK Dharma Wanita 02 agar memiliki pengetahuan dan kreatifitas untuk menyelesaikan masalah tersebut, sehingga akhirnya mereka dapat mewujudkan dan menerapkan Lembaga TK yang Unggul dan Tangguh berbasis Pekarangan di Tengah Pandemi Covid-19. Hal ini sesuai dengan tugas guru, yakni dengan menjalankan proses belajar mengajar diluar kelas. Belajar mengajar diluar kelas secara khusus adalah kegiatan belajar-mengajar antara guru dan murid, namun tidak dilakukan di dalam kelas, tetapi dilakukan di luar kelas atau alam terbuka, sebagai kegiatan pembelajaran siswa. ${ }^{18}$

Kegiatan belajar mengajar di luar kelas disebut juga dengan pembelajaran outdoor. Pembelajaran outdoor merupakan satu jalan bagaimana kita meningkatkan kapasitas belajar anak. Anak dapat belajar secara lebih mendalam melalui objek-objek yang dihadapi dari pada jika belajar di dalam kelas yang memiliki banyak keterbatasan.

15 Irfatul 'Ulum, “Pemanfaatan Lingkungan Sebagai Sumber Belajar Anak,” Jurnal Pendidikan Anak 3, no. 2 (2017).

16 Yesmizarti Muchtiar and Dessi Mufti, “Optimasi Penggunaan Pekarangan Sekolah Sebagai Media Pembelajaran (Studi Kasus : SD Citra Almadina Padang)," Jurnal Pengabdian Kepada Masyarakat Teknik (JPMT) 1, no. 1 (2018): 27-35.

17 Ibid.

18 Adelia Vera, Metode Mengajar Anak Di Luar Kelas (Yogyakarta: Diva Press, 2012). 
Lebih lanjut, belajar di luar kelas dapat menolong anak untuk mengaplikasikan pengetahuan yang dimiliki. Selain itu, pembelajaran di luar kelas lebih menantang bagi siswa dan menjembatani antara teori di dalam buku dan kenyataan yang ada di lapangan. Kualitas pembelajaran dalam situasi yang nyata akan memberikan peningkatan kapasitas pencapaian belajar melalui objek yang dipelajari serta dapat membangun keterampilan sosial dan personal yang lebih baik. ${ }^{19}$ Pembelajaran yang dilaksanakan di luar kelas yakni memanfaatkan Pekarangan Sekolah. Seperti yang dikatakan oleh sudjana dan rivai, ${ }^{20}$ bahwa Pekarangan merupakan salah satu tempat atau wahana untuk digunakan sebagai media dan sumber belajar dalam proses belajar mengajar, karena dapat menumbuhkan minat dan membuka wawasan siswa dalam belajar, terutama bagai anak usia dini. Terlebih dalam penelitian yang dilakukan oleh Abdulrasyid dkk ${ }^{21}$ mendapati bahwa dari banyak sekolah yang memiliki pekarangan sekolah, lebih banyak dijadikan lapangan olahraga sehingga mengurangi area hijau di sekolah. Wadah pekarangan sekolah yang tidak memadai untuk belajar tentang lingkungan seperti kegiatan penanaman pohon dan bercocok tanam, akan membuat kesadaran lingkungan siswa menjadi rendah.

Maka untuk mencapai target awal pendampingan tersebut, fasilitator harus melakukan pendekatan kepada masyarakat atau pengelola, dalam hal ini fasilitator sudah melakukan inkulturasi agar mengetahui karakter dan memiliki ikatan emosional dan juga sebagai usaha untuk melakukan pendekatan kepada komunitas TK Dharma Wanita 02 agar tercapai target awal dan beberapa hal yang dilakukan dalam tahap 5-D yakni Define, Discovery, Dream, Design dan Deliver. ${ }^{22}$

Alasan-alasan utama yang menjadikan fasilitator melakukan pendampingan di komunitas TK Dharma Wanita 02 adalah selain SDM guru yang sangat antusias terhadap perubahan, terdapat asset pekarangan sekolah serta pekarangan kantor desa sukosari yang saling terintegrasi menjadikan pendampingan ini semakin menemukan signifikansinya, serta banyaknya masyarakat dan dukungan aparatur desa yang mensupport. Tetapi sebenarnya alasan yang terpenting adalah agar aset yang dimiliki oleh komunitas TK Dharma Wanita 02 dapat dimaksimalkan seoptimal mungkin agar tidak mubaddir jika tidak dilakukan pembenahan dan pengembangan.

Fasilitator bersama membantu komunitas TK Dharma Wanita 02 memahami kendala dan tujuan mereka untuk bersama-sama mewujudkan apa yang diinginkan baik dalam pembuatan rencana, tata kelola manejemen dan pengembangan sarana. Dalam hal

${ }^{19}$ Suherdiyanto, "Penerapan Metode Pembelajaran Di Luar Kelas (Out Door Study) Dalam Materi Permasalahan Lingkungan Dan Upaya Penanggulangannya Pada Siswa MTs Al-Ikhlas Kuala Mandor B," Sosial Horizon: Jurnal Pendidikan Sosial 1, no. 1 (2014): 95-108.

${ }^{20}$ Sudjana and Rivai, Media Pengajaran (Bandung: Sinar Baru Algensido, 2002).

21 Abdul Rasyid Tolangara and Rohima Wahyu Ningrum, "Pendampingan Komunitas Sekolah Melalui Kegiatan Vertical Garden Untuk Mewujudkan Sekolah Dasar Berbasis Lingkungan Di SDN 34 Kota Ternate Maluku Utara," Engagement : Jurnal Pengabdian Kepada Masyarakat 2, no. 1 (2018): 62-70.

22 Tamam and Fahimah, "Pengembangan Agrowisata Berbasis Komunitas Melalui Program Edukasi Wisata Dan Entrepreneurship Menuju Kemandirian Ekonomi Masyarakat.” 
ini fasilitator tidak memaksakan kehendak melainkan mendorong dan membantu mereka untuk mencapai apa yang belum terwujud. Melalui kegiatan-kegiatan pendampingan yang terlaksana, fasilitator membangun kepercayaan pengelola untuk terus mewujudkan mimpi. Semua pihak dan komponen di komunitas TK Dharma Wanita 02 yang harus bersatupadu bersama-sama membangun kepercayaan agar bisa menggapai mimpi untuk perubahan yang lebih baik.

Pendekatan berbasis aset atau ABCD ini membutuhkan riset dasar, monitoring dan kinerja outcome, menegaskan langkah untuk mewujudkan masa depan yang diinginkan. Tahap ini merupakan tindakan baru dan inovatif dengan memusatkan pada komitmen dan arah ke depan baik individu maupun komunitas. Setelah guru-guru komunitas TK Dharma Wanita 02 mampu melihat dan mendayagunakan kemampuannya, maka meraka akan melakukan tindakan yang mengarah pada strategi dan model pembelajaran yang dipergunakan dalam kegiatan belajar mengajar. Proses ini tidak bisa selesai atau berhenti setelah pendampingan usai, melainkan perlu keberlanjutan yang konsisten.

Pendekatan aset ini mendorong setiap individu guru yang berada di komunitas TK Dharma Wanita 02 untuk memulai proses perubahan dengan memaksimalkan aset yang mereka punya yakni pekarangan sekolah. Harapannya adalah dari peningkatan kualitas sumber daya manusia guru akan bisa melakukan pengembangan secara maksimal yang berdampak pada semakin bervariasinya media dan sumber belajar yang digunakan oleh guru. Sehingga akan timbul kesadaran jika semua asset telah dioptimalkan oleh komunitas TK Dharma Wanita 02 maka daya saing pembelajaran dengan sekolah-sekolah PAUD lainnya bisa sejajar bahkan lebih unggul dari yang lainnya. Selaras seperti penelian yang sudah dilakukan oleh Yesmizarti dan Desi Futi ${ }^{23}$ Kurangnya sarana dan kreatifitas dari sekolah akan menghambat produktifitas anak. Makanya sangat dibutuhkan bantuan dari pihak luar untuk membuka wawasan tersebut.

Aspek keberlanjutan yang dirasakan adalah para guru komunitas TK Dharma Wanita 02 mulai memahami kekurangan yang ada dan pada akhirnya bersama-sama mewujudkan keinginan mereka. Kekurangan yang dimaksut disini adalah kurang maksimalnya proses pembelajaran disebabkan karena tidak memanfaatkan asset yang ada, yakni pekarangan sekolah. Keberdaan fasilitator sebenarnya tidak begitu penting selagi mereka menyadari apa kekurangan yang dibutuhkan sehingga akan berusaha mengurai kekurangan tersebut dan bersama-sama intern komunitas TK Dharma Wanita 02 memajukan lembaganya.

Prinsip penting dari pendekatan ini adalah memulai dengan analisa kekuatan dan kapasitas lokal. Pendekatan ini juga tidak hanya memfokuskan pada guru tetapi juga pada semua unsur pendukung komunitas TK Dharma Wanita 02 baik itu siswa, wali siswa,

${ }^{23}$ Muchtiar and Mufti, "Optimasi Penggunaan Pekarangan Sekolah Sebagai Media Pembelajaran (Studi Kasus : SD Citra Almadina Padang).” 
komite, aparatur desa, asosiasi dan lainnya sehingga mereka bersama-sama mempunyai keinginan untuk memajukan komunitas TK Dharma Wanita 02 dengan mengeluarkan kemampuan dan pengetahuan yang mereka miliki sehingga semua merasa berdaya dan memilki akan komunitas TK Dharma Wanita 02, tentunya dengan pendampingan yang dilakukan fasilitator lewat pelatihan tentang Lembaga TK yang Unggul dan Tangguh berbasis Pekarangan di Tengah Pandemi Covid-19 yang sudah dilakukan.

\section{Kesimpulan}

Sebagai uapaya meningkatkan kualitas proses belajar mengajar pada aspek peningkatan asset SDM guru maka pendampingan ini fokus pada kegiatan-kegiatan yang mampu meningkatkan profesionalisme Guru TK Dharma Wanita 02 dalam hal pemanfaatan pekarangan sekolah sebagai media dan sumber belajar siswa. Kegiatan yang telah dilaksanakan di antaranya pelatihan dan Pendampingan dengan Tema "Pengembangan Kualitas Guru TK dalam Menciptakan Lembaga TK yang Unggul dan Tangguh berbasis Pekarangan di Tengah Pandemi Covid-19”. Penyusunan proses pendampingan dalam menciptakan sekolah pekarangan, dan Program Launching Lembaga TK yang Unggul dan Tangguh berbasis Pekarangan di Tengah Pandemi Covid19. Dengan mengoptimalkan pemanfaatan pekarangan sekolah tersebut menjadi sarana edukasi bagi siswa, sehingga siswa dan guru merasakan manfaat dari pemanfaatan pekarangan sekolah di TK Dharma Wanita 02 sebagai salah satu alternatif media dan sumber belajar pendukung pembelajaran di sekolah.

\section{Pengakuan}

Kegiatan Pengabdian yang dilakukan oleh fasilitator ini tidak akan berjalan dengan baik apabila tidak didukung oleh berbagai pihak, yakni IAI Al-Qodiri Jember yang diwakilkan oleh pihak LP3M IAI Al-Qodiri Jember, Mahasiswa PIAUD IAI Al-Qodiri Jember, Dewan Guru dan Wali Murid TK Dharma Wanita 02, IGTKI Kabupaten Jember, Aparatur Desa Sukosari, Tokoh Masyarakat Beserta Tokoh Masyarakat Desa Sukosari. Maka fasilitor mengucapkan terimaka kasih bagi pihak-pihak yang sudah disebutkan tersebut. 


\section{Daftar Referensi}

'Ulum, Irfatul. "Pemanfaatan Lingkungan Sebagai Sumber Belajar Anak." Jurnal Pendidikan Anak 3, no. 2 (2017).

Abdul Rasyid Tolangara, and Rohima Wahyu Ningrum. "Pendampingan Komunitas Sekolah Melalui Kegiatan Vertical Garden Untuk Mewujudkan Sekolah Dasar Berbasis Lingkungan Di SDN 34 Kota Ternate Maluku Utara." Engagement: Jurnal Pengabdian Kepada Masyarakat 2, no. 1 (2018): 62-70.

Anam, Nurul. Buku Pedoman Kuliah Kerja Mahasiswa (KKM) Berbasis Asset Based Community Development (ABCD) Tahun Akademik 2019/2020. Jember: LP3M IAI AlQodiri Jember, 2020.

Habibi, M. Analisis Kebutuhan Anak Usia Dini (Buku Ajar S1 PAUD). Yogyakarta: Deepublish, 2018.

Kartika. "Perlukah Anak Diikutkan PAUD?" Kompas.Com.

Muchtiar, Yesmizarti, and Dessi Mufti. “Optimasi Penggunaan Pekarangan Sekolah Sebagai Media Pembelajaran (Studi Kasus : SD Citra Almadina Padang).” Jurnal Pengabdian Kepada Masyarakat Teknik (JPMT) 1, no. 1 (2018): 27-35.

Pendis, Dirjen. “Keputusan Direktur Jenderal Pendidikan Islam Nomor 3091 Tahun 2020 Tentang Paradigma Pengabdian Kepada Masyarakat Tahun 2020." Kementerian Agama, 2020.

Solehuddin. Konsep Dasar Pendidikan Prasekolah. Bandung: FIP IKIP Bandung, 1997.

Sudjana, and Rivai. Media Pengajaran. Bandung: Sinar Baru Algensido, 2002.

Suherdiyanto. "Penerapan Metode Pembelajaran Di Luar Kelas (Out Door Study) Dalam Materi Permasalahan Lingkungan Dan Upaya Penanggulangannya Pada Siswa MTs Al-Ikhlas Kuala Mandor B." Sosial Horizon: Jurnal Pendidikan Sosial 1, no. 1 (2014): 95-108.

Tamam, Ahmad Badrut, and Siti Fahimah. "Pengembangan Agrowisata Berbasis Komunitas Melalui Program Edukasi Wisata Dan Entrepreneurship Menuju Kemandirian Ekonomi Masyarakat." Engagement: Jurnal Pengabdian Kepada Masyarakat 4, no. 1 (2020): 100-115.

Taufiq, Amal, and Habib R. "Revitalisasi Kelompok Wanita Tani (KWT) Melalui Pemanfaatan Pekarangan Rumah Di Desa Metesih Kecamatan Jiwan Kabupaten Madiun." Engagement : Jurnal Pengabdian Kepada Masyarakat 2, no. 2 (2018): 204220.

Tim. Panduan KKN ABCD, UIN Sunan Ampel Surabaya: Asset Based Community-Driven Development ( $A B C D$ ). Pusat Penelitian Dan Pengabdian Pada Masyarakat. Surabaya: SAP Pressfile://C:/Users/LENOVO/Downloads/scholar (16).ris, 2016. 
Vera, Adelia. Metode Mengajar Anak Di Luar Kelas. Yogyakarta: Diva Press, 2012.

Wajdi, Muh Barid Nizarudin. "Spiritual Counseling As An Alternative Problem Solving." Educatio : Journal of Education 1, no. 2 (October 30, 2016): 11-28. Accessed October 18, 2017. http://ejournal.staimnglawak.ac.id/index.php/educatio/article/view/27.

Walujo, D. A., and A. Listyowati. Kompendium PAUD. Memahami PAUD Secara Singkat. Depok: Prenadamedia Grup, 2017.

Widyastuti, Titiek, and Rini Juni Astuti. "Penataan Halaman Sekolah Sebagai Ekoedukasi." Berdikari : Jurnal Inovasi dan Penerapan Ipteks 4, no. 1 (2016): 54-62. 